\title{
FINDING COMPETITORS AND STRATEGIES IN MARITIME TRANSPORTATION OF FRUITS AND VEGETABLES IN SPAIN
}

\author{
NICANOR GARCÍA ÁLVAREZ ${ }^{1}$, LAURA CALZADA-INFANTE² \& BELARMINO ADENSO-DÍAZ ${ }^{2}$ \\ ${ }^{1}$ Port Authority of Gijon, Spain \\ ${ }^{2}$ Engineering School, Campus Gijon, University of Oviedo, Spain
}

\begin{abstract}
Complex network analysis (CNA) has appeared as a flexible tool to model systems in multiple fields. With the nodes representing the entities of the system, and the links the relationships among them, CNA allows a topological characterisation of the system, assessing its structure. In recent years, researchers have shown an interest in modelling maritime traffic as a complex network, for analysing connections and relationships among different stakeholders. This paper proposes to model the maritime traffic flow of some food products, traded internationally. The model considers the traffic flows from Spain, allowing to group the partner countries whose traffic flow patterns are similar. These groups (communities), can help decision makers to identify their direct competitors and search for alliances or new markets comparing themselves with those ports that have similar infrastructures. The abovementioned procedure is applied to the export traffic of fruit, vegetables and legumes. Spain is the main fruit and vegetable producer in the EU, the first exporter in the EU and the third in the world. In the Spanish fruit and vegetable sector, part of the products are exported to the EU partly by land, but Spanish ports play a critical role in the transport of this type of goods. The importance of exports to other countries, which are mainly carried out by sea, makes it particularly interesting to study the role of Spanish ports in the export of this type of goods, and the possibilities of improving maritime traffic of these cargo for the Spanish port system. The conclusions derived from the analysis of the export connectivity of Spanish ports for the goods studied are presented, with some of the most important ports for these goods being geographically distant from the production areas, but with a high land connectivity with these regions.
\end{abstract}

Keywords: network analysis, competition, maritime traffic, port communities.

\section{INTRODUCTION}

According to the latest official data available [1], Spain is the leading EU producer of fruit and vegetables with more than $25 \%$ of European production and sixth worldwide, exceeding 28 million tonnes produced in 2017. This accounts for more than $50 \%$ of vegetable production, followed by citrus fruits $(24 \%)$ and sweet fruit $(11 \%)$.

These fruit and vegetable exports and imports are transported mainly using refrigerated trucks, being this sector highly dependent of road transport, so the possibility of transporting long-distance imports and exports by sea can help to reduce $\mathrm{CO}_{2}$ emissions, reduce vehicle accidents and avoid congestion on land transport lines.

Maritime transport, as the backbone of international trade (representing more than $80 \%$ of total traffic) is one of the key sectors in which it is most necessary to promote sustainable development. It is not surprising that international organisations are focused on developing effective long-term policies to achieve this sustainability with, among other initiatives, the 2030 Agenda, the Sustainable Development Goals and the Paris Agreement [2].

Achieving such sustainability is not possible without solutions that involve increasing both public and private investments. Therefore, additional resources are required to increase the resources available to achieve a real improvement in the market share of intermodal 
freight transport with initiatives such as the use of short sea shipping and other systems that are more sustainable than today's majority road transport.

This paper aims to review the maritime transport of agricultural products, focusing on the export of fruit, vegetables and legumes in Spain. These traffics will be analysed by calculating the communities formed by Spanish ports and the countries with which these ports have export flows for the aforementioned goods.

The calculation of these communities allow to identify ports with similar characteristics in export traffics, and thus allows ports to identify their competitors for these traffics or to analyse possible alliances that could be formed. The analysis of the communities will also help to discover possible business opportunities with countries that are part of the same community of a given port, but which do not yet have traffic for the analysed commodities.

This paper is structured as follows: the introduction; Section 2, which reviews relevant literature regarding the maritime transport of agricultural products, Section 3, which provides information about the data analysis and the methodology used; Section 4, which deals with the results obtained, and Section 5, with the final conclusions.

\section{RELEVANT LITERATURE}

The transport of Spanish fruit and vegetables has been studied by several researchers, given the importance of the sector. The handling of fruit and vegetables and their transportation to the final consumer presents several challenges at all stages of the process, such as production, harvesting, packaging, transport, storage and distribution [3]. Therefore, any improvement in the processes can have an impact on the quality of the product. In particular, in the stages related to the logistic chain where maritime transport can bring added value.

Both combined maritime-land, and intermodal transport have been shown to be more sustainable than traditional road transport. Specifically, Pérez Mesa and Aballay [4] demonstrate that the option of exporting products from the high fruit and vegetable production area of Almeria (Andalucía, Spain), using the maritime connection between Bilbao and Portsmouth achieves a cost saving of $26 \%$ with more than acceptable timing differences.

An analysis of horticultural exports from southeast Spain shows that the cost of intermodal transport is $14 \%$ lower than land transport, but total transit time for intermodal transport is almost twice that for land transport [5] which shows both the wide room for growth of maritime transport for fruit, vegetables and legumes and the difficulty of the change to intermodal transportation the Spanish market. This has also been supported by more recent studies, and led to the conclusion that intermodality and the use of "Short Sea Shipping" can be a solution to the saturation of road transport, specifically for the export of these goods in the South East of Spain [6].

In maritime transport, there are plenty of examples of studies that focus on the search for network communities. Jung et al. [7] found community structures in disaggregated cargo flows of the global maritime trade using community-detection algorithms to identify natural communities. Parola et al. [8] investigated inter-firm communities through network analysis. Liao et al. [9] detected the community structure in practical supply chains based on complex networks, while [10] presented an efficient method to identify port communities. Ducruet and Zaidi [11] focused on the analysis of community structures, providing evidence about the role of geography, technology and trade in the maritime networks, and Ansorena [12] determined the community structure of the liner shipping network.

These examples make it clear that the detection of communities in maritime transport can help to understand the relevant players in certain traffics. In particular, using these ideas ports can identify both potential competitors and potential alliances to gain access to new markets, 
but it is important to highlight the possibility of establishing regular shipping lines may be impossible for a port without the contribution of traffic from other ports to make such lines economically profitable.

\section{DATA ANALYSIS AND METHODOLOGY}

As mentioned, CNA has been applied in multiple fields to represent complex systems [13]. This representation considers the entities of the system and the relationships among them. The entities can keep relevant information of the entities, as the links. So, different links or nodes can be considered in the same network depending on the decision-maker approach. In the case of maritime traffic, CNA has been applied considering firms [14], world regions [15], carriers and cooperative agreements [16] among others.

In this case, the system is modelled taking into account the total traffic among ports using tons transported considering as entities the Spanish ports and the countries that trade with Spain by sea with export flows by sea coded in Spanish customs as fruit, vegetables or legumes. The source of the data has been collected by the Bases Portuarias Company [17]. Some ports, which are closed enough and belong to the same region, has to be studied together as the information cannot be disaggregated. These groups of ports are easily identified due to the name of nodes are separated by a hyphen "-".

All the residual traffics or those traffic flows that do not contribute higher $1 \%$ of flow movements of the ports are not considered in the analysis. The removal of ports and countries with a residual contribution of these traffics to the Spanish port system results in export flows with nine ports (or groups of ports) and 47 countries for export flows of fruits, vegetables and legumes.

The purpose of clustering the entities of a system is to detect the tendency of some entities to be more connected among them, or even detect patterns as homophily when similar entities are highly connected. There are multiple approaches to detect these clusters [18]. This paper uses a flow model which is based on flow calculations gathering those entities where the flow stays for long term once it passes through their members [19]-[21]. Random walks go through the network considering the direction of the links and can jumps to a random entity in the network with a "teletransportation probability" to ensure that the result is independent on the initial position of the random walker. The random walks are encoded following the Huffman code [22] and keeping a short code for all those entities which are visited frequently.

\section{RESULTS}

The export of these products is dominated by the port of Valencia (with more than a third of the total traffic) followed by the ports of Algeciras-Cádiz and Barcelona.

The application of clustering algorithms to this traffic detects a large community formed by the ports of Valencia, Seville, Castellon and Cartagena along with 13 other countries and whose detail can be seen in Table 1.

Despite the great dominance of the port of Valencia in this traffic, the most important link appears between the ports of Algeciras and Cadiz with Morocco (Fig. 1), although the links between the port of Valencia and the United States and Saudi Arabia move a high volume of products. They appear in second and third position.

It is worth noting the large number of links between the port of Bilbao. As it was mentioned in Section 2, Bilbao has proven to be a feasible route for the export of fruit and vegetable products produced in geographically remote regions, such as the south-east of the Iberian Peninsula. The other main flows from Bilbao, apart from the specified in Table 1, are Chile, Qatar, Australia among others. It proves the geographical diversity countries for 
Table 1: Communities, main export countries and missed potential markets for export flows, in 2019. Size means number of ports + number of countries in the community.

\begin{tabular}{|c|c|c|c|c|}
\hline Cluster & Size & Port & Main export countries & Missed potential markets \\
\hline 1 & $1+14$ & Bilbao & Algeria, South Africa, Mexico & \\
\hline \multirow{4}{*}{2} & \multirow{4}{*}{$4+13$} & Valencia & $\begin{array}{l}\text { United States, Saudi Arabia, } \\
\text { Canada }\end{array}$ & Germany, Haiti, Ireland \\
\hline & & Sevilla & $\begin{array}{c}\text { Canada, Saudi Arabia, } \\
\text { Colombia }\end{array}$ & $\begin{array}{c}\text { Algeria, France, Ireland, } \\
\text { Israel, Italy, Poland, Taiwan }\end{array}$ \\
\hline & & Castellón & Canada, China, Brazil & $\begin{array}{l}\text { Germany, Algeria, France, } \\
\text { Haiti, Italy, Poland, Taiwan }\end{array}$ \\
\hline & & Cartagena & $\begin{array}{c}\text { Saudi Arabia, Canada, United } \\
\text { States }\end{array}$ & $\begin{array}{c}\text { Algeria, Egypt, France, } \\
\text { Haiti, Ireland, Israel, Italy, } \\
\text { Poland, Taiwan }\end{array}$ \\
\hline 3 & $1+13$ & Barcelona & $\begin{array}{c}\text { Brazil, United Arab Emirates, } \\
\text { Saudi Arabia }\end{array}$ & \\
\hline 4 & $1+3$ & Huelva & Brazil, Canada, United States & \\
\hline 5 & $1+3$ & Las Palmas & $\begin{array}{c}\text { Netherlands, United Kingdom, } \\
\text { Cape Verde }\end{array}$ & \\
\hline 6 & $1+2$ & $\begin{array}{l}\text { Algeciras- } \\
\text { Cádiz }\end{array}$ & $\begin{array}{l}\text { Morocco, United Kingdom, } \\
\text { United States }\end{array}$ & \\
\hline
\end{tabular}

Bilbao flows export. Despite the high number of flows from Bilbao, its total volume of export tones is not as a high as than other ports as Valencia, Algeciras-Cadiz, Barcelona or Las Palmas (Fig. 1).

\section{DISCUSSION AND CONCLUSIONS}

In the previous sections, it has been shown that only nine of the 28 ports studied had significant traffic in terms of exports of the traffic studied, with significant traffic being understood as traffic that contributed at least $1 \%$ of the total traffic during the year studied, in this case during 2019.

The Spanish port system is made up of 46 ports of general interest, managed by 28 port authorities. Although in this article these port authorities are grouped by their province of origin, a clear specialisation in the transport of these goods is therefore observed due to the small number of ports or groupings of ports with significant export traffics for the commodities considered. There is also a clear predominance of the first three most important ports for these exports: Valencia, Algeciras-Cádiz and Barcelona, which account for $72 \%$ of the traffic studied, followed at a great distance by the port of Las Palmas with $8 \%$ of exports and very much focused on banana exports.

According to data from the Spanish Federation of Associations of Producers and Exporters of Fruit, Vegetables, Flowers and Live Plants for the year 2019 [23], more than $90 \%$ of Spanish exports of these products were destined for the European Union, with Germany being the main buyer with $26.3 \%$ of total exports.

It can be observed that the most distant destinations, where traffic will necessarily be routed by sea and where air transport is the only alternative, account for a small percentage of the total volume of exports of this type of product, but some initiatives such as the Motorways of the Sea and short sea shipping with regular lines represent an acceptable 


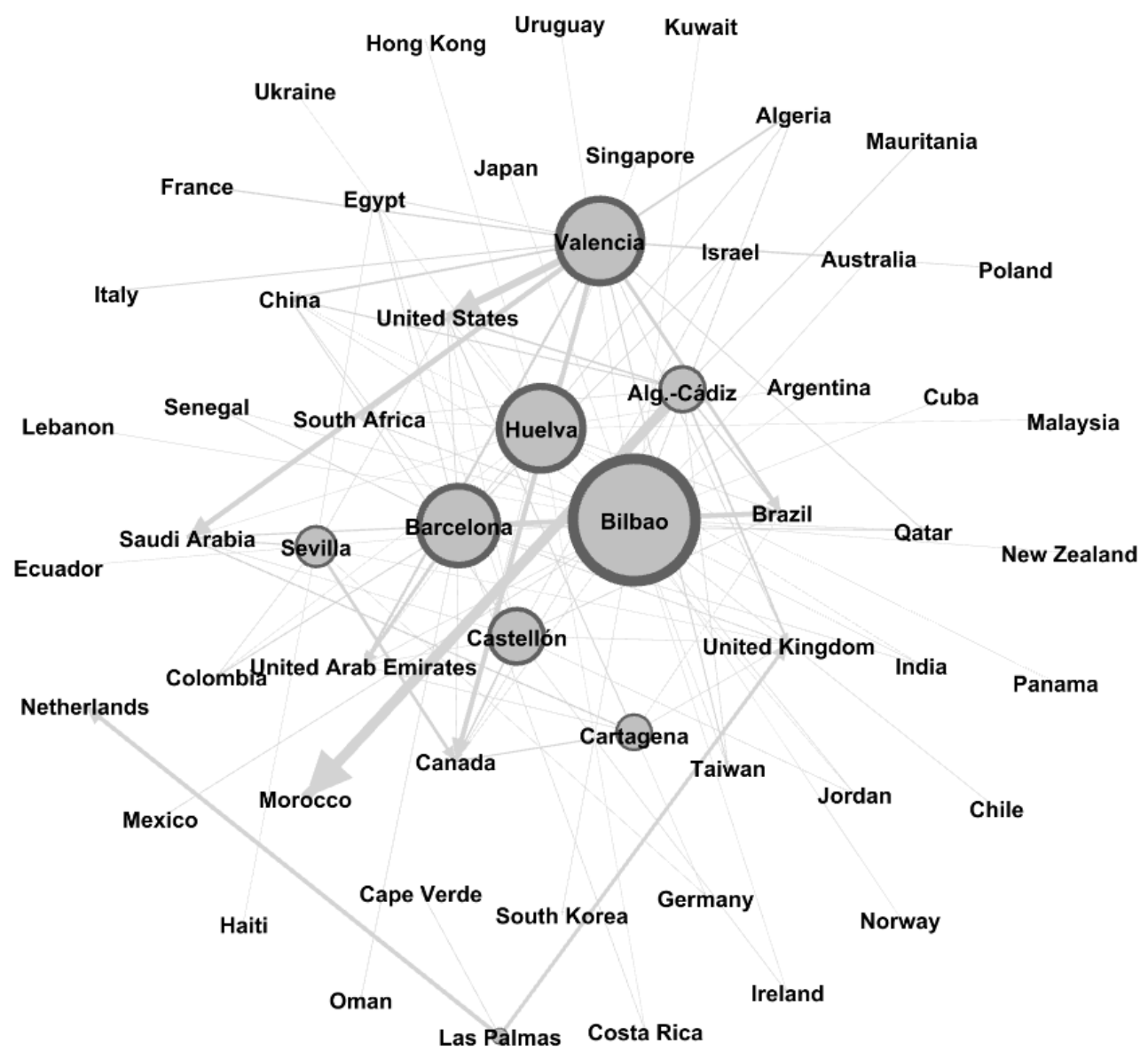

Figure 1: Main export links for fruits, vegetables, legumes in 2019. Nodes and arrows are proportional to the degree of the node and the weight of the link respectively.

alternative to road transport, which is currently the main mode of transport for this type of product in Spain.

It is noteworthy that ports nearby large Spanish fruit and vegetable producing areas, such as the port of Almeria, do not present large export flows but although not included in the present study, it has been verified that it presents import flows of this type of goods. According to data from the Port Authority of Almeria itself [24], in its annual report for 2019, only $20 \%$ of the traffic for this type of products corresponds to exports, with $80 \%$ of the traffic being imports of fruit, vegetables and legumes in a port located in the heart of one of the most important producing areas of these goods in Europe.

With the current systems of storage and transport (mainly by lorry) in this area, it is estimated that the transport of one thousand tonnes of fruit and vegetable products by road from Almeria to their destination markets emits between 58 and 130 tonnes of $\mathrm{CO}_{2}$, depending on the product transported and the destination market being the dominant export markets France and Germany [25]. 
There is a clear potential for the development of intermodal transport in general and maritime transport in particular in the area, which could certainly be helped by the effective development of European Union policies for the implementation of corridors. One of the most important is the Trans-European Transport Networks (TEN-T) whose Mediterranean corridor could help to reduce the impact in terms of carbon footprint and the arrival of fruit and vegetable products from south-east of Spain to all European markets throughout the European Union in a more efficient and environmentally friendly way.

The study of the resulting communities for export flows leads to the conclusion that the ports on the Mediterranean coast have very important flows with the countries of the Persian Gulf, mainly with Saudi Arabia, one of the markets with the greatest purchasing power and of reference in the Middle East.

The communities formed by the ports and countries in the previous section can be used for strategic decision making by the managers of the port authorities involved with different approaches. One of the most obvious strategic approaches may be to search for competitors for a given traffic. Ports with similar traffic: those included in the same community will undoubtedly compete for the traffic of the countries included in that community.

This competition does not necessarily mean that one of the players involved in such competition loses traffics: it is also possible to establish alliances so that multiple ports can work together on regular lines to certain countries in order to compete with land transport, which is currently predominant, and thus effectively involve maritime transport in the supply chain in a cost-effective and environmentally sustainable way.

The study of the communities formed can be a decision-making tool for a port system such as The Spanish port system to support the creation of the aforementioned Motorways of the Sea between various ports in the same port system, which can take advantage of their synergies to create new lines to nearby destinations that currently have land transport as their only alternative. This would imply aligning with the European directives and having the possibility of taking advantage of the existing funding lines for the development of intermodality and offering alternatives to road transport of this type of goods, which is not exempt of problems and with transport issues at certain periods of time.

The further research of the same type of cargo in other port systems and the comparison of the communities created in these systems could help to validate the work carried out for fruit, vegetables and legumes exports in the Spanish port system. Likewise, the contextualisation of the study of these communities with those created for other types of goods, or the creation of communities for longer time series, so that their temporal evolution could be analysed, could help to validate this research as an effective tool for strategic decision-making for the port authorities or for people involved in strategic decision-making in the port sector.

Port strategies for decision making in terms of incentivising important traffic such as regular lines, or commercial strategies for attracting traffic must be taken on the basis of a consistent analysis of the available data. For this reason, it is important to consider not only data from short time-series, but also a comparison that allows the data to be analysed over several years. Therefore, it would be of great interest for further research to analyse longterm data. Furthermore, once enough data are available, the application of algorithms and machine learning methods could provide decision-makers with simulations on future trends for the port traffics considered and therefore give them the possibility of anticipating the competition, establishing appropriate commercial strategies, or searching for alliances with emerging ports that could give them a competitive advantage which, if the evolution of the ports is as expected, will be impossible to establish given their dominant position. 


\section{ACKNOWLEDGEMENTS}

This research was carried out with partial financial support from the Spanish Ministry of Science and the European Regional Development Fund (ERDF) grant DPI2017-85343-P. The authors are grateful to Eduardo Oviedo for allowing access to Bases Portuarias database.

\section{REFERENCES}

[1] Frutas y Hortalizas; Gobierno de España. https://www.mapa.gob.es/es/agricultura/ temas/producciones-agricolas/frutas-y-hortalizas/informacion_general.aspx. Accessed on: 22 Feb. 2021.

[2] UNCTAD, El transporte de mercancías sostenible en apoyo de la Agenda 2030 para el Desarrollo Sostenible, 2019. https://unctad.org/system/files/official-document/cimem 7d17 es.pdf. Accessed on: 25 Feb. 2021.

[3] Shewfelt, R.L., Prussia, S.E. \& Sparks, S.A., Challenges in handling fresh fruits and vegetables. Postharvest Handling, Academic Press, pp. 11-30, 2014.

DOI: 10.1016/B978-0-12-408137-6.00002-8.

[4] Pérez Mesa, J.C. \& Aballay, L., Viabilidad de la intermodalidad en el transporte de perecederos. Estudios de Economia Aplicada, 37(1), pp. 35-46, 2019.

DOI: 10.25115/eea.v37i1.2575.

[5] Perez-Mesaa, J.C., Galdeano-Gomez, E. \& Salinas Andujar, J.A., Logistics network and externalities for short sea transport: An analysis of horticultural exports from southeast spain. Transport Policy, 24, pp. 188-198, 2012.

DOI: 10.1016/j.tranpol.2012.08.010.

[6] Pérez-Mesa, J.C., Aballay, L., Serrano-Arcos, M. \& Sánchez-Fernández, R., Analysis of intermodal transport potentials for vegetables export from southeast Spain. Sustainability, 12(20), p. 8502, 2020. DOI: 10.3390/su12208502.

[7] Jung, P.H., Kashiha, M. \& Thill, J.C., Community structures in networks of disaggregated cargo flows to maritime ports. Information Fusion and Intelligent Geographic Information Systems (IF\&IGIS'17), eds V. Popovich, M. Schrenk, J.C. Thill, C. Claramunt \& T. Wang, Springer: Cham, pp. 167-186, 2018.

DOI: 10.1007/978-3-319-59539-9_13.

[8] Parola, F., Satta, G. \& Caschili, S., Unveiling co-operative networks and 'hidden families' in the container port industry. Maritime Policy and Management, 41(4), pp. 384-404, 2014. DOI: 10.1080/03088839.2013.782442.

[9] Liao, H., Shen, J., Wu, X.T., Chen, B.K. \& Zhou, M., Empirical topological investigation of practical supply chains based on complex networks. Chinese Physics B, 26(11), p. 110505, 2017. DOI: 10.1088/1674-1056/26/11/110505.

[10] Pan, J.J., Bell, M.G.H., Cheung, K.F., Perera, S. \& Yu, H., Connectivity analysis of the global shipping network by eigenvalue decomposition. Maritime Policy and Management, 46(8), pp. 957-966, 2019. DOI: 10.1080/03088839.2019.1647587.

[11] Ducruet, C. \& Zaidi, F., Maritime constellations: A complex network approach to shipping and ports. Maritime Policy and Management, 39(2), pp. 151-168, 2012.

DOI: $10.1080 / 03088839.2011 .650718$.

[12] Ansorena, I.L., Bilateral connectivity in the liner shipping network: An overview. World Review of Intermodal Transportation Research, 7(4), pp. 295-309, 2018. DOI: 10.1504/WRITR.2018.095255.

[13] Costa, L.D.F. et al., Analyzing and modeling real-world phenomena with complex networks: A survey of applications. Advances in Physics, 60(3), pp. 329-412, 2011. DOI: 10.1080/00018732.2011.572452. 
[14] Palmieri, A., Parola, F., Song, D.W. \& Baglieri, E., Integrating firms in a complex network: Evidence from maritime logistics. International Journal of Logistics Research and Applications, 22, pp. 64-77, 2019.

DOI: $10.1080 / 13675567.2018 .1474860$.

[15] Xu, M., Li, Z., Shi, Y., Zhang, X. \& Jiang, S., Evolution of regional inequality in the global shipping network. Journal of Transport Geography, 44, pp. 1-12, 2015. DOI: 10.1016/j.jtrangeo.2015.02.003.

[16] Caschili, S., Medda, F., Parola, F. \& Ferrari, C., An analysis of shipping agreements: The cooperative container network. Networks and Spatial Economics, 14(3), pp. 357377, 2014. DOI: 10.1007/s11067-014-9230-1.

[17] Otras bases de datos, Bases Portuarias. http://www.basesportuarias.com/otras-basesde-datos. Accessed on: 9 Aug. 2020.

[18] Fortunato, S., Community detection in graphs. Physics Reports, 486(3-5), pp. 75-174, 2010. DOI: 10.1016/j.physrep.2009.11.002.

[19] Bohlin, L., Edler, D., Lancichinetti, A. \& Rosvall, M., Community detection and visualization of networks with the map equation framework. Measuring Scholarly Impact, Springer: Cham, pp. 3-34, 2014. DOI: 10.1007/978-3-319-10377-8_1.

[20] Rosvall, M. \& Bergstrom, C.T., Maps of random walks on complex networks reveal community structure. Proceedings of the National Academy of Sciences of the United States of America, 105(4), pp. 1118-1123, 2008. DOI: 10.1073/pnas.0706851105.

[21] Rosvall, M., Axelsson, D. \& Bergstrom, C.T., The map equation. The European Physical Journal Special Topics, 178(1), pp. 13-23, 2009.

DOI: $10.1140 /$ epjst/e2010-01179-1.

[22] Huffman, D.A., A method for the construction of minimum-redundancy codes. Proceedings of the IRE, 40(9), pp. 1098-1101, 1952.

DOI: 10.1109/JRPROC.1952.273898.

[23] Exportación/importación españolas de frutas y hortalizas, Fepex. https://www.fepex.es/datos-del-sector/exportacion-importacion-espa\%C3\%B1olafrutas-hortalizas. Accessed on: 15 Mar. 2021.

[24] Autoridad Portuaria de Almería. Memoria Anual 2019, 2019. https://apalmeria.com/ wp-content/uploads/2021/01/memoria2019-castellano.pdf. Accessed on: 25 Feb. 2021.

[25] Lo-Iacono-Ferreira, V.G., Viñoles-Cebolla, R., Bastante-Ceca, M.J. \& Capuz-Rizo, S.F., Transport of Spanish fruit and vegetables in cardboard boxes: A carbon footprint analysis. Journal of Cleaner Production, 244(118784), 2020.

DOI: $10.1016 /$ j.jclepro.2019.118784. 